\title{
Yogyakarta netizen community response to the black campaign: the 2014 presidential election in Indonesia
}

\author{
Pratama Dahlian Persadha ${ }^{\mathrm{a}, \mathrm{b}}$, Irwan Abdullah ${ }^{\mathrm{c}}, \mathrm{S}$. Bayu Wahyono $^{\mathrm{c}}$ \\ ${ }^{a}$ Communication and Information Security Research Center, Jalan Moh. Kahfi 1. no.88D Jagakarsa, \\ JakartaSelatan, Indonesia, pratama@cissrec.org \\ ${ }^{b}$ Graduate program of culture and media research study, Gadjah Mada University, Jogjakarta, Indonesia \\ 'Dept. of Anthropology, Faculty of Cultural Sciences, Gadjah Mada University, Jogjakarta, Indonesia
}

\begin{abstract}
This research examines the netizen communities' reception of the 'black' campaigning before the Indonesian Presidential Election of 2014, especially focuses on how the general public gave meaning to the black campaigns presented textually through online mass media (specifically okezone.com and detik.com) in the run-up to the Indonesian Presidential Election. The findings state that netizen communities' reception to the black campaigning in the lead-up to the election was not homogenous, but rather depended greatly on background factors such as political ideology, social status, cultural background, past experiences, and family characters. Public belief in the content of the black campaigns also varied; some believed the negative rumors being spread, whereas others did not believe these rumors at all. It is obvious that the black campaigning through the new media generally did not influence netizen communities' perceptions, but rather reinforced their own political preferences that had already divided them into groups supporting specific candidates. In receiving the messages and rumors spread by black campaigns through online mass media, netizens did not act as individuals, but rather as collectives united by specific political ideologies and socio-cultural values which were socialized through family institutions.
\end{abstract}

Keywords: 'black' campaigns; netizens; public reception; online media; Yogyakarta

\section{Introduction}

New media has become an increasingly important part of various aspects of Indonesian social life, including the economy, politics, society, and culture. This cannot be separated from the increased degree of internet penetration in Indonesia. Surveys indicate that, in the past three years, the number of internet users in the country has increased significantly. Data from several institutions focused on the dynamics of internet use in Indonesia have supported this, and even shown a sharp increase in internet use since 2010.

The Indonesian Association of Internet Service Providers (Asosiasi Penyelenggara Jasa Internet Indonesia, or APJII) reports that internet penetration rates in Indonesia for 2012 were $24.23 \%$. Indonesia Investment reports a higher rate for 2013, stating that internet penetration in Indonesia had reached $28 \%$ (representing 71.19 million users). This figure increased to $34.9 \%$ in 2014, as shown by a survey conducted by APJII in collaboration with the Center for Communications Studies of the University of Indonesia (Marius \& Anggoro, 2014: 9-10). This increased internet penetration suggests that new media's role in the future will only grow in importance.

The important role of new media has also been shown in the dynamics of Indonesian politics and the post-New Order democratization process. Social media users act as contestation mechanisms between different political parties in their efforts to gain or maintain power. The rise of terms such as digital democracy, cyber democracy, and democracy on the internet indicates the serious attention given 
by politicians and academics to this phenomenon. Social media has provided an online public space for discussion of political agendas. Before every political event-including presidential elections, particularly since the implementation of direct elections-new media are used increasingly often to collect support for candidates.

This occurred during the Indonesian Presidential Election of 2014 (henceforth Pilpres 2014). Social media was widely used to collect support through campaign activities. Various forms of social media were used by the candidates and their running mates (Prabowo Subianto-Hatta Rajasa and Joko Widodo-Jusuf Kalla) to seek constituent support. These included online media such as okezone.com, detik.com, as well as online media that was integrated with printed newspapers (i.e. kompas.com, republika.com, tempo.com, mediaindonesia.com, merdeka.com, etc.). The involvement of social media in Pilpres 2014 contributed to an increasingly contested campaign situation, with stiff competition for constituent support.

The situation became increasingly conflictive in the lead-up to Pilpres 2014 when, after several would-be candidates dropped out of the race, only two were left: Prabowo Subianto (better known as Prabowo) and Joko Widodo (popularly known as Jokowi). The Indonesian people were sharply divided by their support for one of the two candidates. Supporters of Prabowo termed themselves the Red-and-White Coalition (Koalisi Merah Putih, or KMP), while supporters of Jokowi identified themselves as the Great Indonesia Coalition (Koalisi Indonesia Hebat, or KIH). This division was not limited to the campaigns; KMP gained the majority of parliamentary seats and took all parliamentary leadership positions. This situation has resulted in competition in almost all areas, and as such the populace's division feels almost permanent.
The contestation between these two groups during the campaign was realized through a variety of campaign styles, ranging from the vulgar to subtle. On both sides, direct campaigning followed the formal procedures determined by the General Elections Committee (Komite Pemilihan Umum, or KPU); this included presidential debates, open campaigning, and discussions in closed forums. Outdoor media, including banners, posters, and billboards, were posted in strategic locations. Campaigning through the mass media was extensive and ran the gamut between news coverage and advertorials. Furthermore, both sides owned their own media-electronic, print, and online-which they used to support their campaigns. Media partisanship was thus a logical consequence of the structural division which emerged during the election campaign.

This situation of intense contestation gave rise to an interesting phenomenon, namely the pervasive practice of 'black' campaigning, which emphasized the rivalry between the two groups and the presidential candidates they supported. Such campaigns were not new in Indonesia, as a democratic country, and indeed can be found in nations which are claimed to be the birthplace of democracy. The case of Barack Obama clearly illustrates how black or negative campaigning has occurred in the United States. The fact that Obama's middle name was Hussein made his religious affiliation continuously questioned.

Black campaigning involves attacking a political opponent by revealing information which is not factual, but rather based on lies or difficult-to-prove accusations. Aside from black campaigns, the term negative campaign is also used to explain this practice in the political process. Negative campaigns exploit the weaknesses or dark secrets of a candidate and may target the candidate, his/her family, and his/her supporters. These campaigns may attack specific visions, actions, beliefs, or behaviors (Howe, 1982; Walter, 1998). 
The black campaigning in the lead-up to Pilpres 2014 presented some interesting phenomena from a media studies perspective. First, the widespread black campaigning proved the theoretical assumption that media influence remained a cornerstone of contestation between candidates and groups before Pilpres 2014. The core argument of this view is that the media has a great ability to influence the general public, who are held to simply accept the messages conveyed to them.

Researchers have presented a "magic bullet" theory of mass communications. Somer and Allen argue that individuals are heavily influenced by media messages, as the media is considered a powerful formant of public opinion (cf. Littlejohn, 2009: 423). Meanwhile, Elisabeth Noelle-Neumann believes that the theory of limited influence has transformed years of interpretations and research findings, and as such an argument for media's ineffectiveness can no longer be maintained. Sandra Ball-Rokeach and Melvin DeFleur have put forth a theory of dependence, one which rejects the causal hypothesis of previous belief - a theory which holds that the media is only capable of influencing pre-existing attitudes. To overcome this, both writers have argued for a broader system of approach. Their model presents integral connections between audiences, media, and general society. In accordance with the theories of use and satisfaction, the theory of dependence holds that the public depends on information from the media to fulfill certain needs and realize certain goals (Littlejohn, 2009: 428).

This conceptual debate has been empirically challenged by the media involvement in black campaigning in Indonesia. As recognized by KPU after the election, Jokowi$\mathrm{JK}$ were victorious in their campaign. KPU's formal tabulation of votes cast during Pilpres 2014 indicated that Jokowi-JK received 53.15 percent of the vote, while Prabowo-Hatta only received 46.85 percent. This tabulation of votes from 33 provinces was formally announced by KPU on 22 July 2014 during a plenary session at the KPU Building on Imam Bonjol Street, Jakarta. This meeting showed that, Jokowi-JK received 70,633,576 votes (53.15 percent), whereas Prabowo-Hatta received 62,262,844 votes (46.85 percent), or 8,370,732 votes fewer than his opponent. The total number of valid votes cast was $132,896,438$. The victory of Jokowi-JK in Pilpres 2014 indicates arguments of media effect are not entirely correct. The general public also acts actively; it does simply accept the messages it receives through the media. The fact that this election underscored the existence of active members of the general populace is interesting for further study, especially in the context of new media, which opens the opportunity for two-way interactions, as well as decentralization and democratization.

As expressed by Pierre Levy (1997) in his book Cyberculture, the internet is an open, flexible, and dynamic informational environment that allows people to develop new knowledge orientations. People are involved in a democratic world which promotes a more interactive society-based allocation of power. The online realm acts as a meeting place of sorts for people to expand their social spheres, create opportunities for new knowledge, and offer spaces for broadly sharing different views (Soukup, 2006: 423).

In any study of active public involvement, it is particularly interesting to examine the position of new media in connection with public understanding of political messages. Black campaigning conducted through new media offers the opportunity for new understandings of public studies. If studies of active public involvement have thus far focused on the old media, which is characterized by centralized production and unidirectional communication, then an examination of how the general public is actively involved in the new media offers the potential to formulate a new thesis or even theory. 
The polarization in public support which occurred during Pilpres 2014 was also reflected in online journalism, as can be seen in the cases of okezone.com and detik.com. Okezone.com was used by Prabowo-Hatta supporters and thus conveyed messages from KMP, even after the election; detik.com, meanwhile, tended to support Jokowi-JK and thus be affiliated with $\mathrm{KIH}$, again even after the election. Research must be conducted to explain the public reception of the black campaigns conducted through both online mass media in their news reports before, during, and after Pilpres 2014.

This study of public reception emphasizes how the general public responded to black campaigns conducted before Pilpres 2014. Audiences cover a range of political, ideological, socio-cultural, and economic backgrounds, thus representing Indonesia's own diverse society. This diversity offers problems which are interesting to examine from a reception perspective. The central research questions of this paper are: How did the social media okezone.com and detik.com construct black campaigns during the lead-up to Pilpres 2014?; how did the general public give meaning to these black campaigns' messages, as conveyed textually through news coverage on okezone.com and detik.com, during the lead-up to Pilpres 2014?; and what background factors influenced the public in its reception of the black campaigns conducted through both media during the lead-up to Pilpres 2014?

\section{Theoretical framework}

This analysis of the general public's reception of political cyberbullying through online media in the Pilpres 2014 campaigns will utilize a reception approach, informed by the theories of active participation, new media, and cyberdemocracy. This does not, of course, preclude the possibility of using other theories, keeping in mind that this study uses a qualitative approach, and as such it uses theories to guide its analysis instead of attempting to prove them. The dynamics in the field are the basis for interpretation in this research.

In media studies, the active public approach emerged from dissatisfaction with the classical Frankfurt School theory that criticized the commercialization and commodification of culture and the media industry. This approach's emphasis on the active public is a rejection of the Frankfurt School's hypothesis that the public is simply a victim of the system in place. In the active public approach, the public is active in both obtaining pleasure from the media (such as television) and in determining its own selections and in giving meaning to the media it consumes. The public is thus a producer of text and technology with its own authority, rather than always being subordinated. Media become a venue for cultural democracy, rather than cultural oppression (Ang, 1996: 8).

Hall's theory of encoding and decoding is directly connected to the active public approach. Media professionals are involved in determining how "raw" social events are encoded within discourse. However, in the second moment, when meaning and message are encoded in the discourse (i.e. are given televisual form), the formal rules of language and discourse can be "freely controlled"; messages become open to polysemy (Storey, 1996: 13). Because of this, the decoding process in Hall's theory is related to the active public argument.

As stated by Hall, in the third moment, when decoding is done by the public, different ways of viewing the world (ideologies) can be freely applied. Members of the public are not faced with the raw social events, but rather discursive translations of these events. If a social event has 'meaning' for these members of the public, then said event will be given its own interpretation and understanding. If no 'meaning' is taken, it may be that the media is not 'consumed'. If meaning is not articulated 

campaign: the 2014 presidential election in Indonesia

through practice, it has no effect (Hall, 1980: 128).

In other words, meaning and message are not simply transmitted. They are both produced: first by the encoder, from the raw material of everyday life, and second by members of the public, as influenced by their positions within other discourses. Every moment operates within its own production conditions. Furthermore, as presented by Hall, the moments of encoding and decoding may not be truly symmetrical. What is intended and what is received may differ. Media professionals may wish for decoding to present the same messages which were encoded, but they cannot ensure or guarantee this. Encoding and decoding are open to a shifting reciprocity, as determined by different conditions of existence. As such, there is the possibility of misunderstanding.

Hall's theoretical position is often used as an alternative to the dominant transmission model used in understanding communication. This model identifies communication as the "process of transmission of a fixed quantity of information - the massage as determined by the sender or source" (McQuail, 2005: 69). It was developed by, among others, Lasswell, who defines mass communication simply: the process of answering who said what to whom, through what channels, and to what effect. Other supporters of this model include Shannon and Weaver, who introduced the mathematical theory of communication with a scientific approach. Similarly, the cybernetic theory of communication assumes that communication is a system.

The transmission model was subsequently criticized through the ritual model, pioneered by James Carey (1975). Carey argued that:

Communication is linked to such terms as sharing, participation, association, fellowship and the possession of a common faith... a ritual view is not directed towards the extension of messages in space, but the maintenance of society in time; not the act of imparting information but the representation of shared beliefs

Communication, according to the ritual model, involves a conveyer of messages and experiences (the sender) and a receiver of messages and experiences (the consumer). This ritual, or expressive communication, depends on mutual exchange of understandings and emotions. Messages, in the ritual model of communication, are generally latent and ambiguous, relying heavily on symbols and associations which are not selected by the participants but rather supported by culture. The reception approach is poorly suited to the assumptions of the transmission model, but is little different from the ritual model of communication as well as the encoding and decoding model of media discourse.

In the 1990s, numerous new technologies emerged or became popular, including desktops, internet, cable television, global satellite television, interactive digital television, and CD-ROMs. This led to the assumption that technological progress was unavoidable and could create significant social change, a view also known as technological determinism. However, not all technologies benefit consumers or are supported by them. Generally, new technologies are met with two types of views. The first is that new technologies increase access to information and thus promote greater empowerment. This assumption is held by those who are often termed cultural optimists. The second view is that multimedia companies will become exceedingly powerful, and thus be capable of greater commercial exploitation and creating a greater gap between the information-rich and information-poor. This assumption is held by those who are often termed cultural pessimists (Sardar, 2008: 156).

Sardar explains that the World Wide Web contains millions of pages of information 
which are saved on computers worldwide. These pages contain text, images, animations, music, and videos; can be accessed using computers and modems; and all contents can be downloaded and saved. This network has the potential to carry all forms of media, from newspapers to film. Films have even been released online, through the internet. Supporters of the web view it as opening a new era of democratization and giving ordinary people greater power to produce and consume information and entertainment from throughout the globe. In other words, one conclusion frequently made is that the internet promotes freedom; if not under any centralized control, the internet can become a true medium for free individuals and small groups to promote an egalitarian world unburdened by national, class, gender, or property boundaries. However, one must ask: has this all happened? It cannot be denied that there are economic aspects which limit access and ownership. The hardware and software sold on the world market, as well as the initial and subscription fees for connection, have actual and significant economic impact (Thwaites et al., 2002: 339).

Despite the ongoing debate between these two poles, it is clear that the use of the internet in almost all aspects of life cannot be avoided. In Indonesia, information access through the internet has increased at a rapid pace, especially in urban areas. Furthermore, as has been shown time and time again, internet access is closely tied to political activity, particularly during presidential, regional, and legislative elections. The campaign teams of different candidates regularly use social or internet media. This has led to the development of such concepts as cyberspace, cyberculture, and also cyberdemocracy.

The concept of cyberspace refers to a nowhere place, where emails are sent freely, where electronic money transfers occur, where digital messages move, and where www sites are accessed. It is, conceptually, a 'place without a space' in which words, human relations, data, wealth, and power are presented by various people who use their computers as communications technology (Ogden, 1994: 715). The main technologies used in this electronic culture are computers, cable systems, satellites, television, video, and virtual reality. These technologies form a 'telematic' domain in which services and infrastructure connect computers through telecommunications networks and using digital technology. The main characteristics of this technology are: electronics, speed, convergence, plurality, and interactivity (Barker, 2000: 330).

Meanwhile, the concept of cyberdemocracy was proposed as part of an optimistic view of the new media's ability to support democratization. One understanding of cyberdemocracy comes from David Bell (2001), who refers to the term cyberculture to explain an environment filled with electronic technology. Owing to the availability of facilities which enable interactive communications, democratic practices which are mediated by the internet have a different character than offline democratic practices. For instance, the anonymity provided by the internet allows the public to more freely express its hopes and aspirations, including through sarcasm and linguistic anarchy.

In culture and media studies, cyberdemocracy is understood in its connection with public space. Mark Poster (2001) examines cyberdemocracy the relationship between public space and the internet. Similar results are presented by Diana Saco (2002), whose research differs only in terminology; Poster uses the term "public sphere", whereas Saco uses the term "public space". Meanwhile, Last Moyo (2009) problematizes the ability of cyberdemocracy to improve public space, instead favoring the term digital democracy.

Meanwhile, the concept of black or negative campaigns is here understood normatively, with reference to Law Number 10 
of 2008 on Elections. Article 84 of this law specifies ten specific acts which may not be committed during election campaigns. First, campaigns may not question or reject the preamble to the Indonesian Constitution of 1945. Second, campaigns may not conduct any acts which endanger the unity of the Republic of Indonesia. Third, campaigns may insult someone (be it a candidate or other election participant) because of his or her race, ethnicity, religion, or group affiliation. Fourth, campaigns may not incite conflict between individuals or communities. Fifth, campaigns may not disturb the public order. Sixth, campaigns may not threaten violence or promote violence against a person, group of people, or other participant in an election. Seventh, campaigns may not damage and/or remove the campaign equipment and media of other candidates/election participants. Eighth, campaigns may not use government facilities, places of worship, or institutions of education. Ninth, campaigns may not carry or use images and/or other attributes aside from the images and/or other attributes of the candidate being campaigned for. Tenth, campaigns may not promise or give money or other materials to campaign participants.

These ten forbidden acts may be categorized as negative campaigning. The first and second acts are forbidden because such campaigns would be unconstitutional (i.e. violate the Indonesian Constitution of 1945). The third and fourth forbidden acts can be termed black campaigning. The fifth, sixth, and seventh acts are forbidden because they are anarchic, promote chaos, or may easily lead to riots and violence. The eighth and ninth acts are forbidden because they are considered covert campaigning. The tenth act is forbidden because it is considered money politics.

As such, based on the definitions found in Article 1, Paragraph 26, and Article 84 of Law Number 10 of 2008 regarding the General Elections of Members of Parliament, Members of the Regional Representation Council, and
Members of Regional Parliaments, black campaigning can be understood as a model, act, or method of campaigning which utilizes insult, defamation, incitation, and lies to promote one candidate over another. Regarding black campaigning, Article 270 of Law Number 10 of 2008 regarding the General Elections of Members of Parliament, Members of the Regional Representation Council, and Members of Regional Parliaments stipulates that persons involved in such campaigns can be imprisoned for at least 6 (six) months and at most 24 (twenty-four) months, and face a fine of at least Rp. 6,000,000 (six million rupiah) and at most Rp. 24,000,000 (twenty-four million rupiah) ${ }^{1}$.

\section{Research method and Analysis}

This research applies a reception study approach while still maintaining the critical character required of ethnography. Regarding reception theory, Barker writes:

... exponents of reception or consumption
studies argue that whatever analysis of
textual meanings a critic may undertake,
it is far from certain which of the
identified meanings, if any, will be
activated by actual
readers/audiences/consumers. By this is
meant that audiences are active creators of
meaning in relation to texts. They bring
previously acquired cultural competencies
to bear on texts so that differently
constituted audiences will work ...
(Barker, 2000)

As a reception study, this research will follow research procedures in stages. There are three core elements to the reception study approach, which can be identified explicitly as "the collection, analysis, and interpretation of reception data" (Jensen, 1999: 139).

For this research project, news stories from okezone.com and detik.com that contained black campaigning were selected. These two sources were selected because, together, they 
represented the rivalry between the two presidential candidates in Pilpres 2014. Okezone.com tended to support Prabowo for president, whereas detik.com tended to support Jokowi.

The following step involved identifying specific news content which formed part of the black campaigns and codifying the central themes covered in the months before the election (May-June 2014). The issues and rumors chosen for this research were selected based on their relevance to the core themes of the negative campaigns in the lead-up to Pilpres 2014. The groundbreaking rumors selected included political ideology (the stigma of communism); religious ideology (Jokowi's Islamic faith was questioned, and he was accused of being Christian $^{2}$ ); racial issues (Jokowi was accused of being ethnic Chinese); capability (Jokowi was depicted as being an impotent fool); physical appearance (Jokowi's slender build, as well as his lack of machismo or conventional good looks, was questioned), militarism (Prabowo was considered authoritarian, a cruel and iron-fisted leader, and undemocratic); human rights violations (Prabowo was reported to have kidnapped human rights activists in 1998 and to be responsible for that year's racially charged riots in Jakarta and Solo); dual citizenship (Prabowo was reported to hold dual citizenship); and bankruptcy (Prabowo was reported to be 14 trillion rupiah in debt and unwilling to pay the wages of the staff at his company PT Kertas Nusantara).

Several of the issues and rumors spread by okezone.com and detik.com were selected to be confirmed with members of the target group in Caturtunggal Village. Confirmation involved the purposive dissemination of survey instruments. After the members of the public who had been exposed/not exposed to these rumors were identified, those who had been exposed to the rumors were given the texts of negative campaign news coverage to reread. The texts of these news stories included the issues and rumors which had already been identified.

During the following stage, the researchers semi-randomly selected members of the general public who could be used as informants, with consideration of their different political affiliations, religions, ethnicities, sexes, and employment background. Following these criteria, this research involved a total of fifteen informants.

\section{Research findings and discussion}

This research has produced several findings. First, netizen communities' reception of the black campaigns during Pilpres 2014 was not homogenous, but rather quite diverse. It was influenced by respondents' political ideology, social status, cultural values, past experiences, and family characteristics. Informants were, indeed, from the beginning of this research project selected to reflect diverse backgrounds. In terms of political ideology, netizen communities' understanding of issues was contextualized mostly by political streams, which remain strong in Yogyakarta. However, during the campaigns before Pilpres 2014, political streams were not manifested as firmly as during that year's Legislative Election. Constituents in Pilpres 2014 were less bound to their political ideologies; the only prominent ones were issues of politicalized Sharia Islam; traditional/cultural Islam, and nationalism. Nevertheless, primordial issues such as different religions, races, and understandings of communism still colored the messages conveyed during online election campaigns.

\subsection{Ideological factors}

Primordial issues were more commonly spread by KMP, which supported Prabowo. These rumors included that Jokowi was not a Muslim, that he had Chinese heritage, and that he was a communist. Such rumors tended to be 
spread by Islamist political groups which promoted the integration of State and religion. These included Islamic political parties such as the Prosperous Justice Party (Partai Keadilan Sejahtera, PKS), the United Development Party (Partai Persatuan Pembangunan, PPP), and, to a certain extent, the National Mandate Party (Partai Amanat Nasional, PAN), all of which were part of KMP. Rumors that Jokowi was a Christian were received in different ways by netizen communities, as influenced by their own party and organizational ideologies. Those who were more Islamist, such as PKS, PPP, and PAN members, were sensitive to the issue of a candidate's Islamic faith. The same held true for respondents with a background in Islamist organizations such as Muhammadiyah, the Islamic Defenders' Front (Fron Pembela Islam, FPI), Hizbut Tahrir Indonesia, and Indonesian Students Action Forum (Kesatuan Aksi Mahasiswa Indonesia, KAMI). As such, when online mass media spread rumors questioning Jokowi's Muslim faith, this reinforced their rejection of the candidate. This group was also very sensitive to rumors of communist ideology and Chinese ethnicity.

For Islamist groups, a candidate's Muslim faith and religious devotion was important; this suggests consideration of the representation of Muslims, who constitute the majority of Indonesia's population. This group was unwilling to allow the Indonesian people, 90 percent of whom are Muslim, to be led by a non-Muslim or by someone whose faith was questionable. As such, these groups, aside from being sensitive to candidates being Muslim/nonMuslim, also utilized such issues to influence constituents. When these groups heard rumors that Jokowi was Christian, they easily believed the rumors and felt very disappointed. This reinforced their rejection of Jokowi's candidacy. These groups often questioned Jokowi's devotion to Islam, despite frequent attempts to neutralize the issue. Respondents who were affiliated with Islamist organizations such as
Muhammadiyah were likewise highly sensitive to rumors of Christianization. The organization's opposition to Christian missionary efforts in Yogyakarta began shortly after Muhammadiyah was established by Ahmad Dahlan, and this criticism of Christianization efforts has been reproduced through strategic institutions such as schools and families. Jokowi and his nominating party, the Democratic Party of Indonesia Struggle (Partai Demokrat Indonesia Perjuangan, PDIP) have often been considered to be close to Christians by leading figures in Muhammadiyah. Some of these leaders even considered Jokowi and PDIP to be at risk of Christian manipulation, with an end goal of converting Muslims to Christianity.

These groups had similar reception to racial rumors that Jokowi had Chinese heritage. Islamist organizations were deeply disturbed by these rumors, and thus resisted Jokowi's candidacy more strongly. This was particularly true in Muhammadiyah, where the ethnic Chinese dominance of the Indonesian economy was a source of anxiety. Members of Muhammadiyah held that the Chinese dominance of the economy limited opportunities for Muslim modernists to do business, even though mercantile culture was strong within Islamic organizations such as Muhammadiyah, the Indonesian Institute for Islamic Preaching (Lembaga Dakwah Islam Indonesia, LDII), and the Council for Quranic Interpretation (Majelis Tafsir Al Qur'an, MTA). These groups hold firm to the Hadith that 9 out of 10 of God's provisions are trade. As such, these groups have a strong rivalry with the ethnic Chinese, as they are all active in trade and business. As such, when Jokowi was targeted by negative campaigns which claimed he had Chinese heritage, these groups rejection of his candidacy was affirmed. Many believed the negative campaign's detailed, point-by-point argument that Jokowi had to be of Chinese descent. 
A different reaction was had among PDIP, National Democrat (Nasdem) People's Conscience Party (Partai Hati Nurani Rakyat, Hanura), and National Awakening Party (Partai Kebangkitan Bangsa, PKB) constituents, who rejected all of the primordial rumors presented online. Supporters of PDIP, Nasdem, and Hanura viewed these rumors as groundless nonsense. The rumors that Jokowi was Christian, communist, or had Chinese heritage were unimportant, meaning that they still supported his candidacy. This group believed that the rumors in question had been deliberately spread by KMP to discredit Jokowi and thus did not believe them. KIH constituents were selective in response to the negative campaigns spread by KMP through the online mass media.

Of particular interest are the respondents with a PKB background. Although $\mathrm{PKB}$ is also considered an Islamic party, specifically a party for traditionalist Muslims, it was critical of the primordial rumors being spread by the black campaigns. Constituents did not simply believe that Jokowi was a Christian or had Chinese heritage. Their reception of the negative campaigns propagated through the online media, at least as related to primordial issues, was critical, or at least permissive. PKB constituents even did not believe the rumors that Jokowi was a communist, even though, historically, traditionalist Muslims such as those in Nahdlatul Ulama came into conflict with communist movements in 1965.

Selective reception of the negative campaigning over primordial issues was also exhibited by some constituents supporting KMP, such as those from the Work Group (Partai Golongan Karya, Golkar) and Great Indonesia Movement (Partai Gerakan Indonesia Raya, Gerindra) parties. Constituents from these parties did not simply believe the rumors which attempted to discredit Jokowi through primordial issues. These netizens questioned the accuracy of these rumors, and tended to not believe that Jokowi was a communist, Christian, or of Chinese heritage. These voters stated that, even though they did not support Jokowi's candidacy, they had not considered such primordial issues. Their considerations, they said, were more rational, having to do with the candidates' respective competence and resources. These respondents, who supported Golkar and Gerindra, believed that Prabowo was more capable of leading the country than Jokowi; they did not mention religious, racial, or communist issues. As such, this group's reception was more critical in the face of negative campaigning.

When faced with rumors spread through detik.com about Prabowo, such as claims that he had violated human rights, was authoritarian, or bankrupt, his supporters generally recognized that these were all part of a negative campaign intended to discredit or commit character assassination on Prabowo in the hopes that his campaign would fail. Whatever was exposed on detik.com was, according to constituents who leaned more heavily towards KMP, an effort to negatively portray Prabowo.

Regarding rumors that Prabowo had violated human rights while an active soldier during the New Order, pro-KMP constituents tended to not care. In general, they did not directly reject Prabowo's involvement, but they argued that it was in the past and thus there was no need to discuss it further. A similar lack of attention was given to rumors that Prabowo was bankrupt or had not paid the taxes for his various businesses. Some even argued that these rumors were false and only intended to besmirch Prabowo's good name.

Pro-KIH netizen communities tended to agree with views that Prabowo had violated human rights as a soldier during the New Order. Rumors that Prabowo had had an important role in creating the May 1998 riots in Jakarta and Solo were likewise supported by KIH, or at least 
used to validate rejection of him as a presidential candidate and decision to support Jokowi. Discourses among KIH supporters also indicated that there was concern that, should Prabowo become president, his style of leadership would be hardline, iron-fisted, and authoritarian, and that he would not heed rules intended to limit presidential power. These views were forms of reception of the negative campaigns conducted online through the mass media. Each message from the negative campaigns conveyed through the online mass media, be it okezone.com or detik.com, was used as part of discourse by netizen communities and interpreted in different ways. Negative campaigning was not simply received as intended by the mass media, but subject to critical consideration.

\subsection{Family institutional factors}

Netizen communities' reception of negative campaigning was also affected by individual family backgrounds. It appears that family, which teaches and promotes values, frequently served as a frame of reference when filtering the negative campaign messages conveyed online and selecting a candidate. When hearing rumors that connected Jokowi with communism, some netizens referred to the values conveyed to them by their families. For those from Islamist or military backgrounds, the issue of communism was a sensitive one. One informant stated that he had been asked explicitly by his father to vote for Prabowo because the candidate originated from a military family. However, the informant attempted to be selective in his vote, and thus considered other aspects of both candidates in the election. This indicates that, among Indonesian Military families, support for Prabowo's presidential candidacy was often expected. When such individuals faced negative rumors about Prabowo, they tended not to be influenced.
Military families were also sensitive to the issue of communism, and as a result, when Jokowi was rumored by black campaigns to have ties to communism, these families often showed resistance. The values conveyed to voters by family (as an institution) tended to have a greater influence on their behavior, and as a result the negative messages conveyed through online mass media generally affirmed pre-existing values. This was particularly common among youths who had little interest in political issues. They tended to vote in accordance with their families' wishes. Admittedly, some informants stated that they had been free in choosing their candidate in Pilpres 2014; some informants even stated that they had voted for a different candidate than their own spouses. However, such views were more commonly expressed by persons who already had greater political awareness and involvement.

Past experiences also shaped informants' views and candidate selection processes. Several informants stated that they had had unpleasant experiences with the military, or had witnessed violence perpetrated by the military with their own eyes. These witnesses were sensitive to human rights issues in the presidential election. Witnessing the riots that occurred in May 1998, for example, served as a reference in candidate selection. Several informants even stated that their families were displeased with the soldiers' behavior, which promoted violence. According to these informants, the media exposure of human rights violations committed by Prabowo supported their own experiences. When the media reported on human rights violations committed by one of the presidential candidates, netizens who had previously had negative experiences with the military received direct affirmation of their views.

In another case, an informant from a santri (devout Muslim) family stated that, in the candidate selection process, he had referred to his family values in regards to the issue of 
communism. Family influence was particularly important in responding to issues of communism and suspected communist ties. The rumors that Jokowi was a communist directly influenced the interpretations of santri families, who related them to the 1965 incident. This can be attributed primarily to the values conveyed by respondents' parents, who experienced the events of 1965 themselves. Some respondents even tied these rumors with the dominance of the ethnic Chinese. If the communists won, they held, it would tantamount to Indonesia inviting a Chinese invasion. Nevertheless, the younger generation attempted to be more autonomous in receiving negative campaign messages. Even when their parents pressured them to use their values and experiences in voting for a candidate, informants tended to consider other aspects as well. As such, in responding to the negative campaigns against the different candidates, as spread by the online mass media, they attempted to remain critical—or at least selective.

Meanwhile, respondents with a communist family background tended to vote for Jokowi. In facing the negative campaigns of both groups, which competed through online mass media, their unpleasant experiences were used as a point of reference. Throughout the New Order, families of former communists received unjust treatment. They faced mockery, discrimination, and limited opportunities for placement within the government bureaucracy. Many of these families with communist backgrounds had traumatic experiences with the military, who had treated them with violence. As such, when rumors that Prabowo had violated human rights were spread, then netizens with a communist family background rejected the candidate even more firmly. Family background and negative experiences with the military could thus sometimes be detrimental to informants' critical appraisal of negative campaigns, even as rumors affirmed their own attitudes. As such, the issue of human rights violations was a sensitive one for netizens originating from former communist families.

\subsection{Cultural factors}

Varied responses were also connected to cultural issues, such as the view that only persons of a priyayi (Javanese nobility) cultural background could be appropriate leaders for the Indonesian people. KMP continuously spread messages that Jokowi was ora wangun (unworthy) of becoming president because he did not have a priyayi cultural background. According to the construction of priyayi culture presented by this group, a president had to be masculine, handsome, and attractive. Jokowi, meanwhile, was said to be unworthy of becoming president because he had the face of a wong ndeso (provincial person), was culun (of slight build), and not handsome. Others argued that Jokowi practiced abangan (Javanese syncretic) culture, and as such was only worthy of becoming a kawula (servant).

KMP's discourse also argued that only a soldier, or at least a person with a military background, was worthy of becoming president. Prabowo was a general in the Indonesian Army and held to be highly masculine and relatively handsome; as such, he was said to meet the physical requirements to be president. The construction of this ideal, that an Indonesian president must have a military background, was deeply grounded in Indonesian history and intensified under the New Order era. Under the New Order, the government used centralized authoritarian politics to promote the view that the only people worthy of occupying a leadership positon, of becoming president, governor, regent, or mayor, were those with a military background. The dichotomy in civilian and military leadership was deliberately constructed to ensure military supremacy. Owing to this politics of appearance, it is not unsurprising that Prabowo was considered more appropriate for president than Jokowi. 
The pro-military and pro-priyayi negative campaign was massively opposed by the KIH, who criticized the messages conveyed. This was manifested, in part, in fanatical support for Jokowi; the more Jokowi was insulted, such as through descriptions of him as wong ndeso, culun, or ora wangun, the more firmly $\mathrm{KIH}$ supported Jokowi's campaign. This indicates empathy of sorts for Jokowi, who was viewed as a leader that was being treated unfairly by the media as part of negative campaigning.

\section{Conclusion and closing remarks}

\subsection{Conclusion}

Following up on these research results, several arguments may be explored which may confirm the theory used. Morley's thesis that there is a significant difference between the ideal reader promoted by the structuralist model and actual audience members (everyday readers) is more or less reflected by netizen communities' reception of negative campaigns launched through online mass media. Morley's argument that audiences are not simply passive subjects, to be deceived by media discourse and respond as desired by the communicators, is also relevant here.

Netizen communities had the ability to be selective in receiving the negative campaigns launched by both competing groups. Each informant argued that the message conveyed by negative campaigns was not a neutral one, but rather one intended to shape public opinion. The assumption that the mass media is capable of wholly controlling the public remains unproven, as netizens had sufficient critical abilities to reduce media influence. All information and messages contained within these negative advertisements could be confirmed through respondents' ideological values, cultural values, family decisions, and knowledge. As such, netizen communities tended to be active when targeted by negative campaigns.

This is not to say that the structuralist view is inapplicable. As shown by this research, netizen communities were not autonomous to social structure. Even though they were critical of the messages conveyed by the mass media, in perceiving the negative campaigns they continued to use structural values. One informant from KIH, for instance, when giving meaning to primordial issues such religion and race, had to refer to political party structures and family values. Similar phenomena were recorded among the KMP, who judged the charges of human rights violations levelled at Prabowo based on the value structures within their political parties.

The research results do, in some points, affirm the thesis of Ian Ang, which centers around the argument that viewers of Dallas were actively involved in meaning and joy production, and that this was manifested in a variety of ways which could not simply be reduced to textual structures, ideological effects, or political products. Viewers develop a critical view of television broadcasting. Ang held that Dallas, in its viewers' eyes, offered emotional realism which readers read at the denotative and connotative levels. Viewing Dallas, as with other television programming, was a selective process. Audiences read the text from denotation to connotation and developed an understanding of the self which was presented both within and without the narration. In this research, netizen communities were likewise critical in their reception of negative campaigning. The readers of okezone.com and detik.com also offered an emotional realism which was read by netizen community members at two the denotative and connotative levels. At first, the reader, when reading and being targeted by negative campaigning, would initially following the meaning contained in the text's structure. However, the process of giving meaning to the text did not end there, as further meaning was 
given at the connotative level. Upon being targeted by negative campaigns, netizens would be critical based on their realization that the text being read had its own context. At this level, readers were seen to realize that the texts were not neutral, but rather contained within them the negative campaigns' interests.

Meanwhile, these research results also show accordance with Hall's theory of encoding and decoding. According to Hall, meaning production does not guarantee that this will be consumed in the manner expected by the encoders, as television messages are polysemic in nature and constructed as a system of signs with various points of emphasis. In short, television messages convey many meanings, and can thus be interpreted in different manners. The same holds true for the negative campaigns which were spread through online mass media: the consumption of meaning was not that expected by the encoders, because such campaigning is itself polysemic. The negative campaign messages hold a variety of meanings, and can thus be interpreted differently, depending on the characteristics of the decoder (general public).

Regarding Hall's thesis of the three positions in coding-dominant-hegemonic coding, which receives 'the desired meaning'; negotiated coding, which abstractly recognizes the legitimacy of hegemonic coding but creates its own rules and adaptations for specific situations; and oppositional coding, in which persons understand the encoding they prefer but reject and decode the encoding they do not prefer-this research shows some confirmation, but also a few unique aspects.

Regarding netizen communities' involvement in dominant-hegemonic coding, each group exhibited different characteristics. Among the KMP, supporters who practiced this form of coding generally had a high degree of education, and many were politically affiliated with PKS and members of Islamist organizations. This group would accept any media constructions related to the negative campaigns, particularly those dealing with primordial issues and directed at Jokowi. A similar pattern could be seen among the KIH supporters, as supporters who practiced this form of coding were affiliated with the PDIP and had a family background of communism. This group believed and accepted all media messages regarding human rights violations by Prabowo. They sincerely believed that the candidate had violated human rights and been involved in the May 1998 riots.

\subsection{Closing remarks}

This research has produced several findings, including, first, netizen communities' reception to the black campaigning in the leadup to Pilpres 2014 was not homogenous, but rather depended greatly on background factors such as political ideology, social status, cultural background, past experiences, and family characters. Second, public belief in the content of the black campaigns varied; some believed the negative rumors being spread, whereas others did not believe these rumors at all. Again, this was influenced by socio-cultural background and political orientation. Third, the black campaigning through the new media generally did not influence netizen communities' perceptions, but rather reinforced their own political preferences that had already divided them into groups supporting specific candidates; netizens, who were already in a dominanthegemonic position, were practically unaffected by the messages and rumors spread by these black campaigns. Fourth, in receiving the messages and rumors spread by black campaigns through online mass media, netizens did not act as individuals, but rather as collectives united by specific political ideologies and socio-cultural values which were socialized through family institutions. 


\section{Notes:}

1. http://dodynurandriyan.blogspot.com/200 9/02/black-campaign.html

2. In the United States presidential campaign, similar rumors emerged which questioned Democratic Party Candidate Barack Obama's Christianity. During the presidential campaign, many in the opposing Republican Party accused him of being Muslim.

\section{Reference}

Ang. Ien. 1985. Watching Dallas. London: Methuen.

Barker, Chris, 2000. Cultural Studies: Theory and Practice. London: Sage Publications. , 2004. Cultural Studies: Teori dan Praktik. Diterjemahkan Nurhadi. Yogyakarta: Kreasi Wacana.

Bennet, Lance. 1996. News: The Politics of Illusion. New York: Longman Publishers.

Carey, James W. 1989. Communication as Culture: Essays on Media and Society. Boston: Unwin Hyman.

Chomsky, Noam. 2006. Politik Kuasa Media. Yogyakarta: PINUS Book Publiser.

Delmer, Denis Sefton. 1962. Black Boomerang. London: Secker and Warburg.

Denton Jr., Rober (ed.). 2010. Studies of Identity in the 2008 Presidential Campaign. Plymouth, U.K.: Lexington Books.
Fakhruroji, Moch. 2014. Agama dalam Pesan Pendek: Mediatisasi dan Komodifikasi Agama dalam SMS Tauhiid. Disertasi. Program Studi Kajian Budaya dan Media, Sekolah Pascasarjana UGM.

Fiske, John. 1990. Cultural and Communication Studies. Yogyakarta: Jalasutra.

Foucault, Michel. 1990. Power and Knowledge. New York: Phanteon.

Good, Do. 2006. Illness Saves: The British WWII Black Propaganda Malingering Campaign. Sussex: Www.psywar.org.

Howe, Ellic. 1982. The Black Game: British subversive operations against the Germans during the Second World War. London: Michael Joseph.

Gorham, Eric. 1992. National Service, Citizenship and Political Education. Albany: State University of New York Press.

Hall, Stuart. 1981. Encoding/Decoding dalam S. Hall, D Hobson, A. Lowe dan P. Willis (ed), Culture, Media, and Language. London: Hutchinson. 
Hall, Stuart. 2006. "Encoding/Decoding", dalam Durham \& Kellner, Media and Cultural Studies: Keyworks. London: Blackwell.

Holmes. David. 2005. Communication Theory: Media, Technology and Society. London: Sage Publications.

Liebes, T. Katz. E. 1991. The Export of Meaning. Oxford: Oxford University Press.

Marijan, Kacung. 2007. "Resiko Politik, Biaya Ekonomi, Akuntabilitas Politik, dan Demokrasi Lokal”, makalah In-House Discussion Komunitas Dialoq Partai Politik, Komunitas Indonesia untuk Demokrasi (KID), Jakarta.

McQuail, Dennis. 2005. Mass Communication Theory. Fifth Edition. London: SAGE Publications Ltd.

McQuail, Dennis. 1987. Teori Komunikasi Massa, terj Agus Dharma dan Aminuddin Ram. Jakarta: Erlangga.

Morley, David. 1980. The Nationwide Audience: Structure and Decoding. London: British Film Institute.

Moyo, L. 2009. "Digital Democracy: enhanching the public sphere" dalam Glen Creeber and Roystone Martin, (ed)., Digital Culture: Understanding New Media. Berkshire-England: Open University Press.

Ogden, M. 1994. Politics in a Parallel Universe: Is There a Future for Cyberdemocracy? Futures, 26(7).

Perloff, R. M. 1995. The dynamics of persuasion. Hillsdale, NJ: Erlbaum.
Poster. Mark. 2001. "Cyber Democracy: The Internet and the Public Sphere". Dalam Trend, David, (ed), Reading Digital Culture. Oxford: Blackwell Publisher.

Rushkoff, Douglas.1994. Media Virus: Hidden Agendas in Popular Culture. Sydney: Random House Australia Pty Ltd.

Sahid, Asep Abdul. 2014. Cyberdemocracy dalam Representasi Calon Gubernur DKI Jakarta di Komentar Kompas.com Tahun 2012. Disertasi. Kajian Budaya dan Media, Sekolah Pascasarjana UGM.

Sardar, Ziauddin dan Borin Van Loon. 2008. Membongkar Kuasa Media. Diterjemahkan Dina Septi Utama. Yogyakarta: Resist Book.

Storey, John. 1996. Culuture Studies and The Study of Popular Culture: Theories and Methods. Athens: The University of Georgia Press.

2007. Cultural Studies dan Kajian Budaya Pop. Diterjemahkan Laily Rahmawati. Yogyakarta: Jalasutra.

Thawaites, Tony. Lloyd Davis, Warwick Mules. 2002. Introducing Cultural and Media Studies: Sebuah Pengantar Semiotik. Diterjemahkan Saleh Rahmana. Yogyakarta: Jalasutra.

Walters, Ronald. 1998. Black Presidential Politics in America: A Strategic Approach. New York: State University New York Press. 